Scottish Geographical Magazine

\title{
The Early Views and Maps of Edinburgh
}

\author{
William Cowan \& Harry R. G. Inglis F.R.S.G.S.
}

To cite this article: William Cowan \& Harry R. G. Inglis F.R.S.G.S. (1919) The Early Views and Maps of Edinburgh, Scottish Geographical Magazine, 35:8, 315-327, DOI: 10.1080/00369225.1919.10749980

To link to this article: http://dx.doi.org/10.1080/00369225.1919.10749980

\section{曲 Published online: 21 Oct 2013.}

Submit your article to this journal

LII Article views: 11

Q View related articles 두 
tish castles to-day. Thus "Auld Reekie" was a very different town in its early days - castle and burgh and abbey all alike clean and shining; as new and practical in the eyes of their builders as Rosyth is to us to day, but with an added quality of ordered civic idealism, whioh is now only being recovered in part in our modern garden villages.

The burgh and abbey were self-contrined units just as the castle was, each having its enclosing fence or wall and ports, and the duties and privileges of the dwellers in each were very clearly defined.

The new burgh of Edinburgh was laid out along the crown of the ridge, and first extended from Castlehill to a point a little east of the Bridges. The long closes ran down the slope on each side to back lanes, of which only the Cowgate on the south remains. The closes on the south of the Cowgate appear to belong to this original setting out, and the King's Wall represents a shrinkage of the town for military reasons; as happened later in Berwick, where the existing fortifications are far within the line of the Edwardian walls.

The Grassmarket was regularised at this time, and appears to have been originally about two-thirds of its present length.

Both the High Street and the Grassmarket must have been originally grass-grown, as are the central spaces of country villages to-day.

Limit of space in this short paper do not permit of a detailed analysis of the structure and organisation of the burgh in its early period: the subject is full of interest, and not without its pointed lessons for the present day.

It is one of the tragic results of mediæval wars and recent utilitarianism that this ancient garden town and capital of Scotland should have come to be labelled as a slum, and it is maintained that only by an understanding of its early character can its present state of squalor be remedied in such a way as to prevent that relapse which has followed too many improvement schemes in the past. But the Civio Survey leads us further than this; it brings to us the vision of the ancient hillcity renewed, not as an improved slum, but as the vital centre of the city's life.

\section{THE EARLY VIEWS AND MAPS OF EDINBURGH.}

\section{By William Cowan and Harry R. G. Inglis, F.R.S.G.S.}

The earliest known fairly authentic representation of Edinburgh is a picture plan (A), illustrating an attack on the eity, believed to be that under the Earl of Hertford in 1544, when the greater part of the town was burnt by the Englizh troops. The city then consisted of two main streets - the High Street with its continuation the Canongate; and the Cowgate widening out into the Grassmarket. An interesting feature of this picture is that the roofs of the houses from the Castle to the Netherbow are coloured red, while those in the Canongate and outside the city walls are coloured grey. The suggestion is that the former were mostly tiled buildings, while the latter were thatched or slated. This plan has all the appearance of being a carefully drawn original. 
Following this appears the absurd View of Edinburgh (B), inserted in Münster's Cosmographia, dated 1550. It is said to be from a description by Alesius - a Scottirh Professor in Germany - but as the picture is not uniform with the rest of the illustrations in Münster's volume, and bears the initials "RMD" at the right-hand side-which initials are not found elsewhere in the work-there is the possibility that it is a picture borrowed from some obscure volume now unknown. The picture is more amusing than reliable.

The next in chronological order-the scene of the murder of Darnley -(C), while not in itself a pieture of the city, gives some idea of the general appearance of the buildings in Edinburgh in 1567. Most noticeable is the predominance of the crow-stepped gable walls of the period, as well as the outside stairs, which can still be seen in older buildings to-day. The picture is evidently not meant to be taken as a consistent whole, as the relative positions of the various buildings are not in accordance with fact.

Next in order is what is believed to be a reproduction of a sketch made to illustrate an account of the siege of the Castle in 1573 (D), when the latter was held for Mary Queen of Scots by Sir Wm. Kirkaldy of Grange, and attacked by English troops under Sir Wm. Drury. The sketch was published in Holinshed's Chronicle, 1577, and is apparently the basis from which the two following pictures were made up.

Of the undated view of Edinburgh (E), published in a collection of "Views of the Principal Cities of the World," by G. Braun and F. Hogenburg in Holland about 1580 , it is difficult to speak with certainty. As a source of information it is of no value, being apparently compiled from hearsay description and not from actual knowledge, while in some respects it bears a great family resemblance to the previous picture. It has been frequently reproduced.

A small copy (F), from Braun and Hogenburg's view, embellished with the picture of a man with swords and " $\mathrm{S}$ 's" issuing from his mouth, is evidently from a German source. From the discourse about anger, it looks as if it were out of some book of moral maxims. It will be obliging if any one can state in what book the picture appears, and at what date.

The double picture of the city by Gordon of Rothiemay (G), was drawn to accompany his picture plan of Edinburgh drawn in 1647, and is here given as probably the first really good picture of Edinburgh. It is unfortunate that it cannot be absolutely trusted in some respects, as Gordon complains that the engraver, by enlarging the views, had falsified the same. This would appear to mean that the proportions of the buildings were not absolutely as in the original sketches.

Shortly after the issue of these two views, Hollar, the famous engraver, issued a picture of Edinburgh from the south $(\mathrm{H})$, which has been much admired. The plate is dated 1670 , but the drawing was probably made some years earlier, as certain buildings are shown which were destroyed by Cromwell in 1650.

The last of the pictures reproduced (I), is more of a curio than an authentic view. The print was published in Paris probably about the 


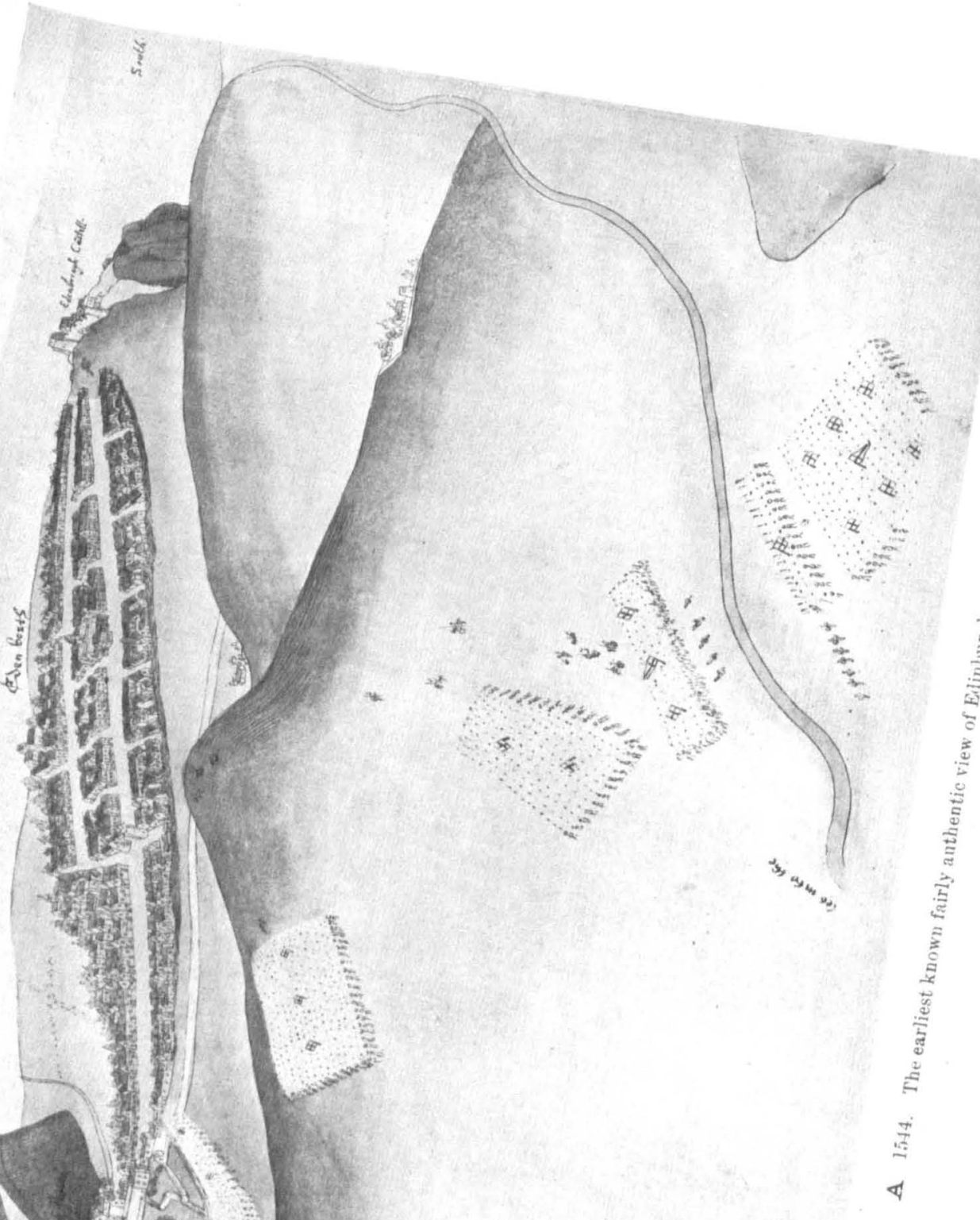




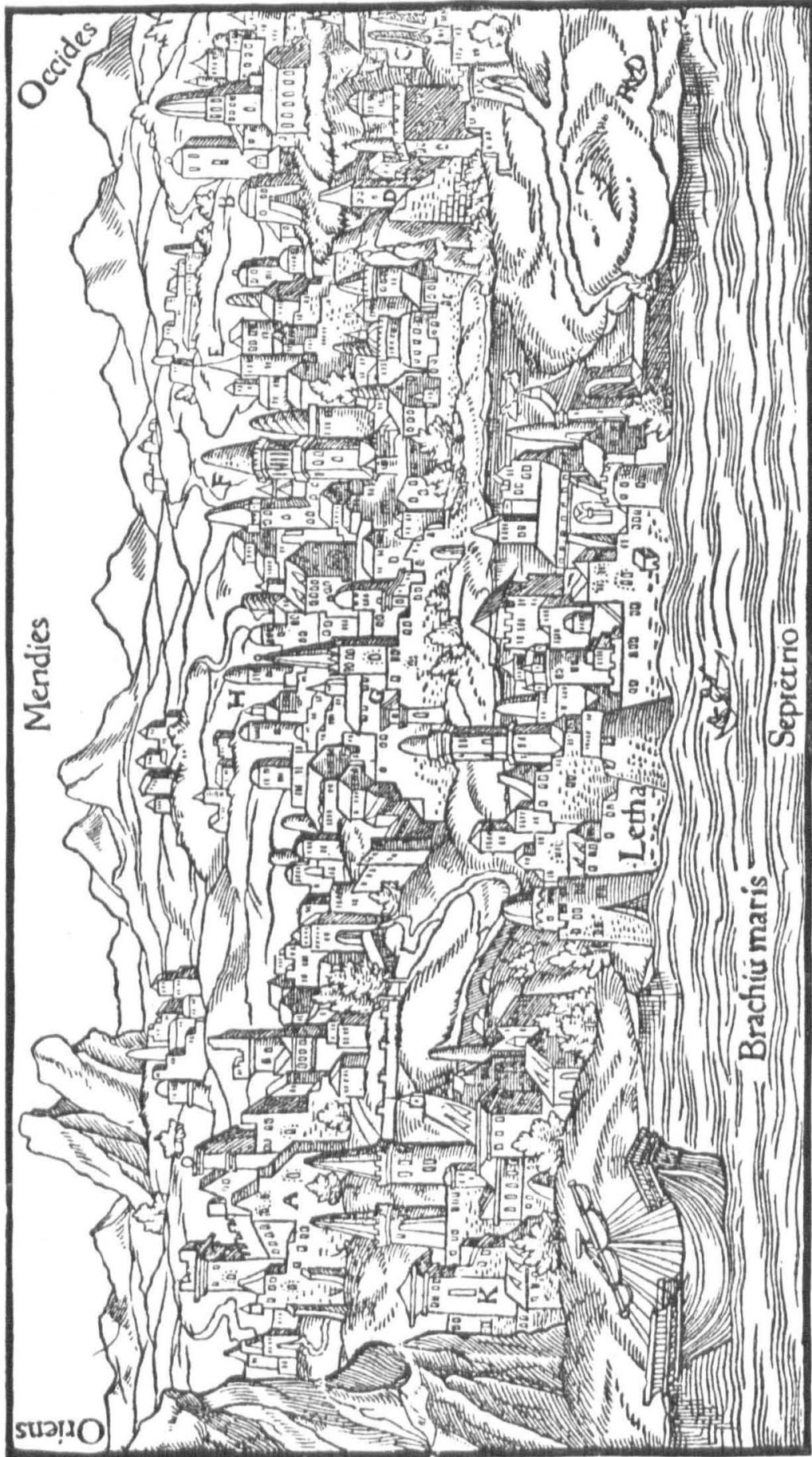


end of the eighteenth century, but from its appearance the view must be of much earlier date, and most of the details are highly imaginary. It will be observed that if the picture is held up to the light and looked at through the back, the positions of some of the buildings and places depicted become rather more intelligible, and it is possible the original engraver had neglected to reverse the picture.

Fuller bibliographical and other information as to the early views of Edinburgh will be found in a paper by William Cowan in Vol. IX. of the Publications of the Edinburgh Bibliographical Society.

When we come to the actual plans of the city, the first of real merit is Gordon of Rothiemay's map (No. 1), surveyed by the assistance and direction of the Town Council in 1647, and of its quality nothing but the highest praise can be given. The features that impress the eye most are the closely packed buildings of the High Street and Cowgate, and the spaciously laid out gardens of the Canongate residences. There are quite a number of reproductions of this plan with slight variations. It was originally engraved by De Wit in Holland cir. 1647, and was re-engraved by Andrew Johnston in London about 1710, and this plate was re-issued by Joseph Smith in 1719, and again by John Bowles in 1819. The two last appeared in Slezer's Theatrum Scotiae.

Practically a hundred years elapsed before the next survey was undertaken. It seems curious that Adair, with all his geographical skill, never appears to have attempted to make a plan of the city during his residence there, when he was making his County maps of the district. No doubt he would be influenced in this by his animosity to Slezer, who, in 1693, produced views of Edinburgh from various points. In 1742, however, a survey of the city was made by William Edgar, whose plan was published in Maitland's History of Edinburgh, 1753. After his survey of Edinburgh, Edgar made one of Dumbartonshire, then of Stirlingshire, followed by Perthshire, when he was drafted into Government service to prepare the maps of the roads through the Highlands to Inverness, the manuscripts of which are in the British Museum. It is stated that he died as the result of the exposure in surveying.

Not long after the '45, a movement towards city improvement was set on foot, the first result of which was the building in the High Street of the Exchange, now the City Chambers. Much more important, however, was the project of an enlargement of the city, by the acquisition of the fields beyond the Nor' Loch, and the erection thereon of a New Town. The first great step towards the realisation of this scheme was the construction of the North Bridge; which was begun in 1763 (but not completed till 1775). At this time Edgar's map was brought up to date and issued in 1765 .

It will be observed that, up to this point, only two really satisfactory plans of Edinburgh had ever been published, but from this time onward these began to be issued in profusion, and as it would be tedious to go into the details of the very numerous maps issued, attention need only be given to those of outstanding importance.

In 1767 Craig presented his Plan of the New Town to the Town Council, and, although a later plan was made showing a great "circus" 


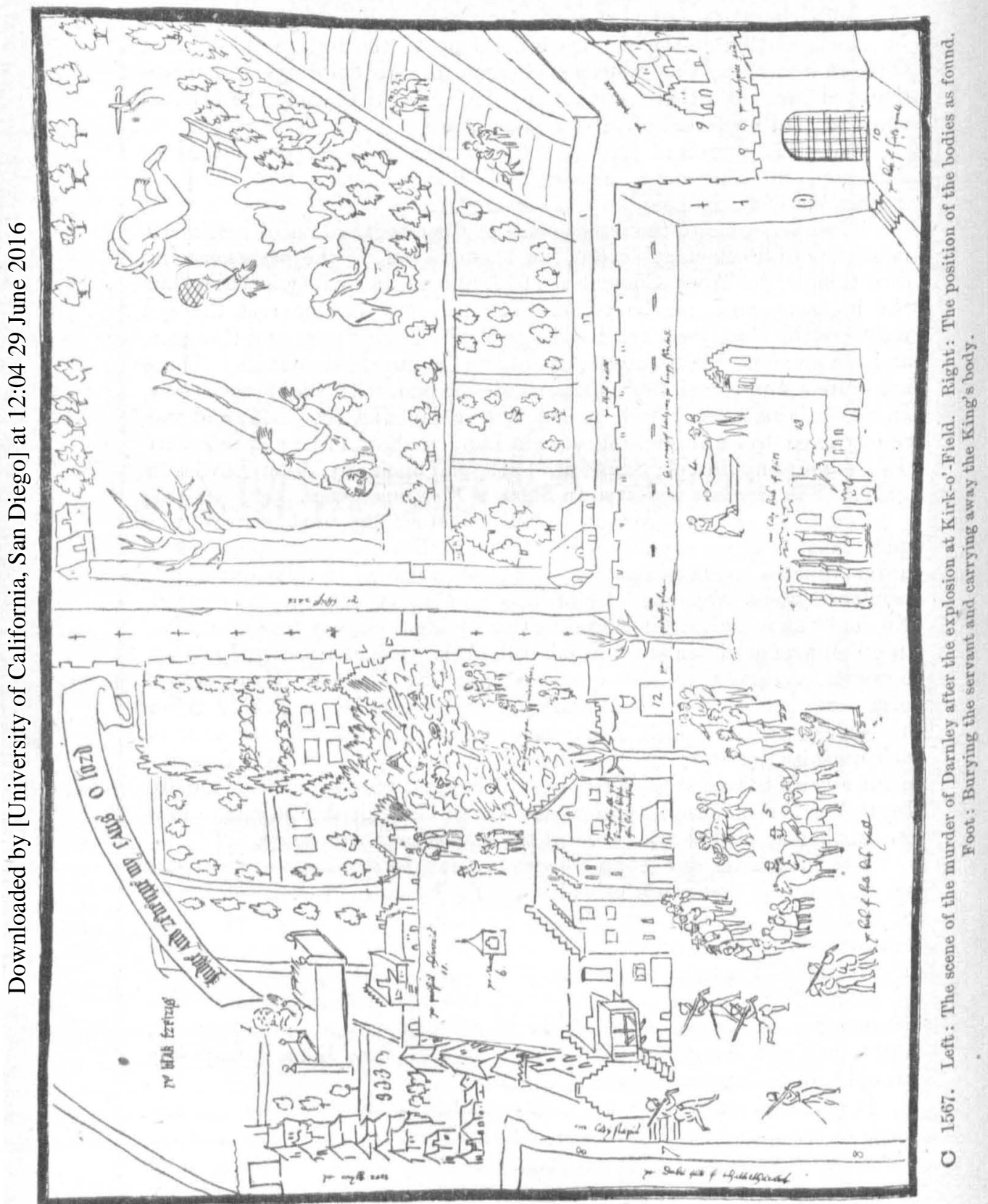


in the middle of George Street (originals in the Municipal Museum), the first scheme was adhered to in the main.

Various small plans were produced shortly after 1767 , but the best and most detailed larger plans were those of Ainslie 1780, and Kincaid 1784. Ainslie as a surveyor had begun with Jedburgh, but his fine work was appreciated, and for the next twenty to thirty years he was one of the leading geographers of the day. As there is no great difference between his map and that by Kincaid, the former is reproduced.

The Edinburgh Directory, which was first issued in 1773 , soon became an annual publication; and the small maps issued in it, as well as in the Guide Books which came into being about the same period, had few special features of their own, as they were almost entirely copied from the larger maps. In tracing the history of these publications at this period and even at a later date, it is frequently difficult to be quite definite, as the majority of these early Directories now available have had the maps torn out, and we are never certain whether some later possessor has not inserted some other available map in its place. It is this fact that creates a difficulty in tabulating these plans, as different copies of the same Directory have been found to have different maps.

In 1804 Ainslie engraved an entirely new map, giving the suburbs, as well as the names of the proprietors of the various properties. The map is extremely useful in verifying the boundaries of old properties.

During the next twelve years the issue of maps was practically confined to those of small size for the general purposes just referred to, and the same plan was made use of in different publications subject to slight alterations and changes in the title and imprint.

In 1817 Kirkwood issued his splendid large map, almost entirely superseding Ainslie's map of 1804. This map is par excellence the finest plan of Edinburgh of the early part of the nineteenth century; and as it includes a large part of the ground now covered by the suburbs, it is a most useful work for purposes of consultation.

Kirkwood followed this in 1819 by a pictorial plan of the New "Town, where we have a beautifully engraved picture of each street, showing the appearance of every building, while the coaching, timber, and farm yards that appear at various points are in themselves interesting studies of detail.

Quickly following these came Knox's plan of 1821-of handier size-and this map was re-issued in 1823 and 1825, when Lothian's similar map appeared, reprinted in 1829,1831 , and again in 1844 , with Laing and Forbes' imprint. This map is of interest to the present generation, as it was engraved by George Bartholomew, the ancestor of the head of one of our best known engraving firms. It is also of interest because it shows the original design for laying out the London Road district, a project that was never carried out-one of those splendid town-planning schemes that somehow fail to materialise.

The Directory Maps at this period show continuous improvement, and various different maps were tried, but in 1834 Lizars issued a new map (dated), and this was used uninterruptedly till 1859 , when W. \& A. K. Johnston obtained the contract. It is unfortunate that 


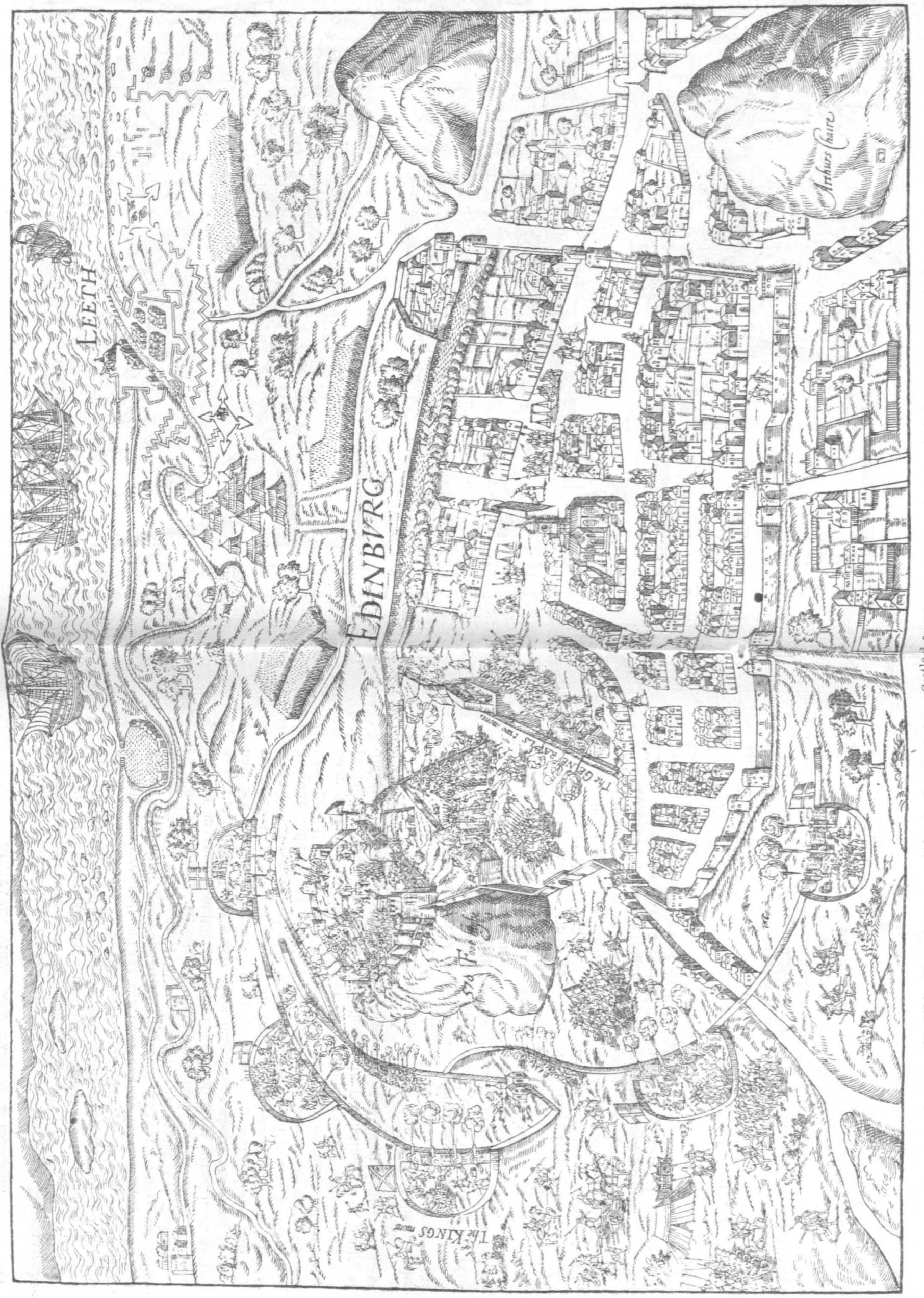




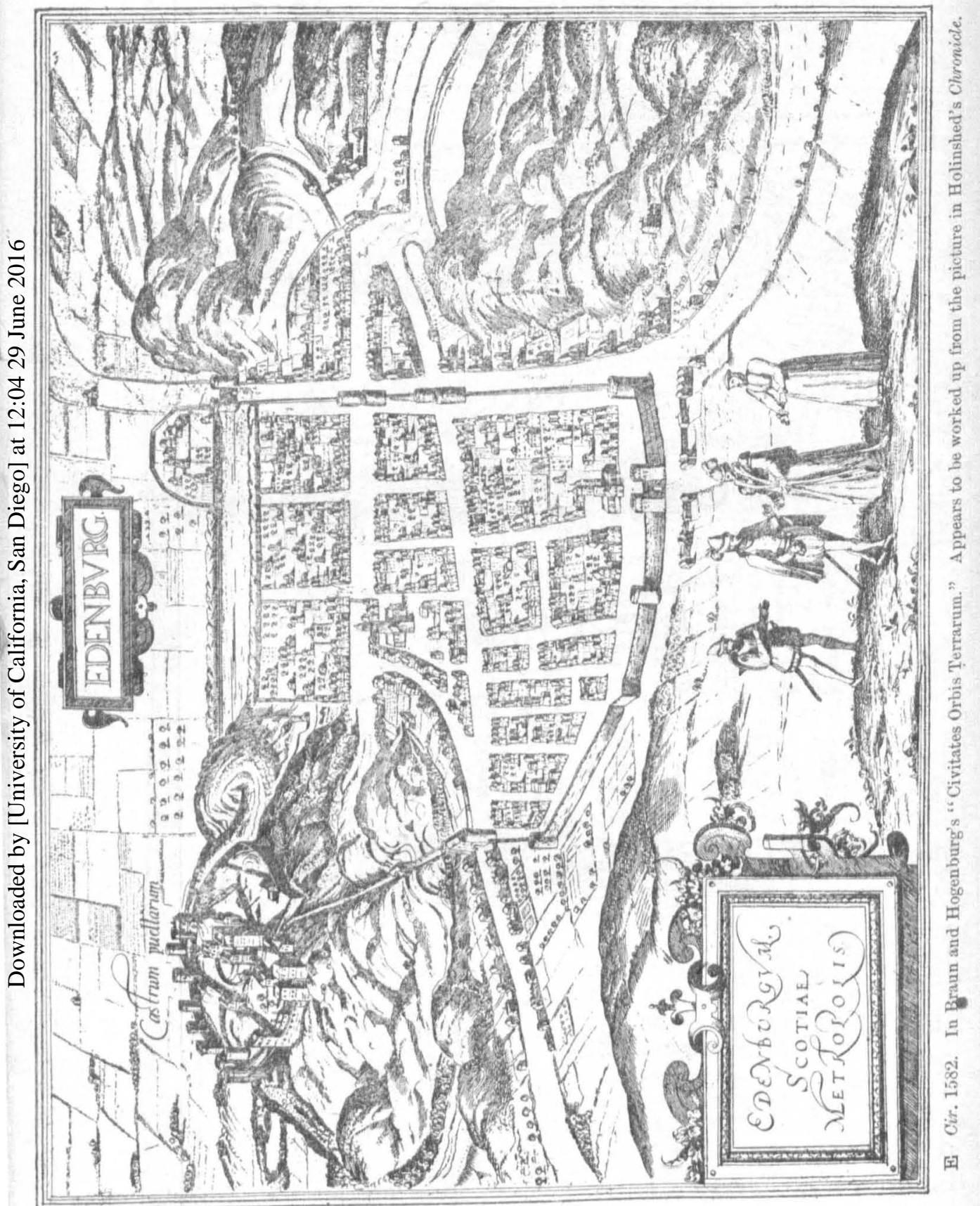




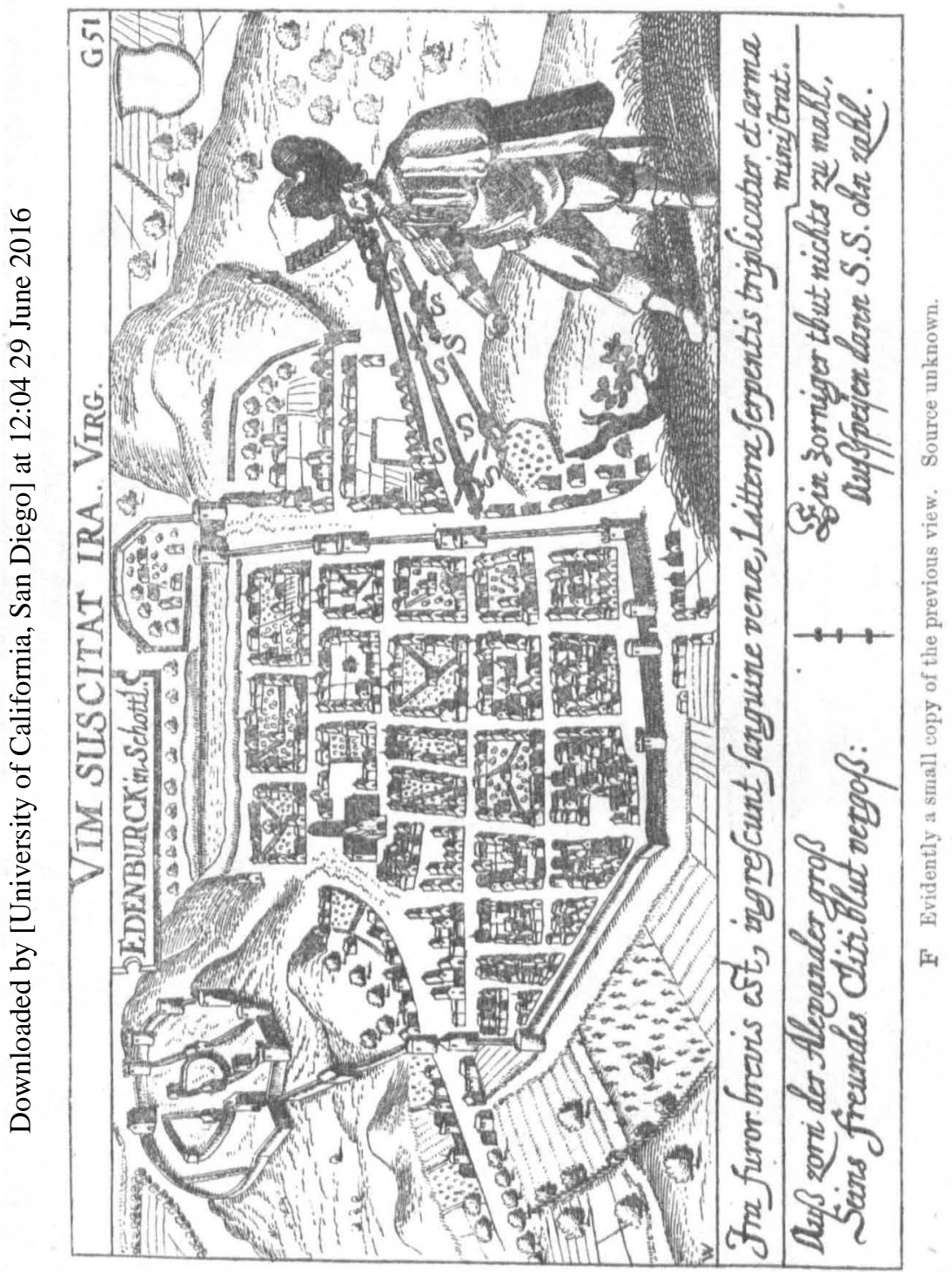




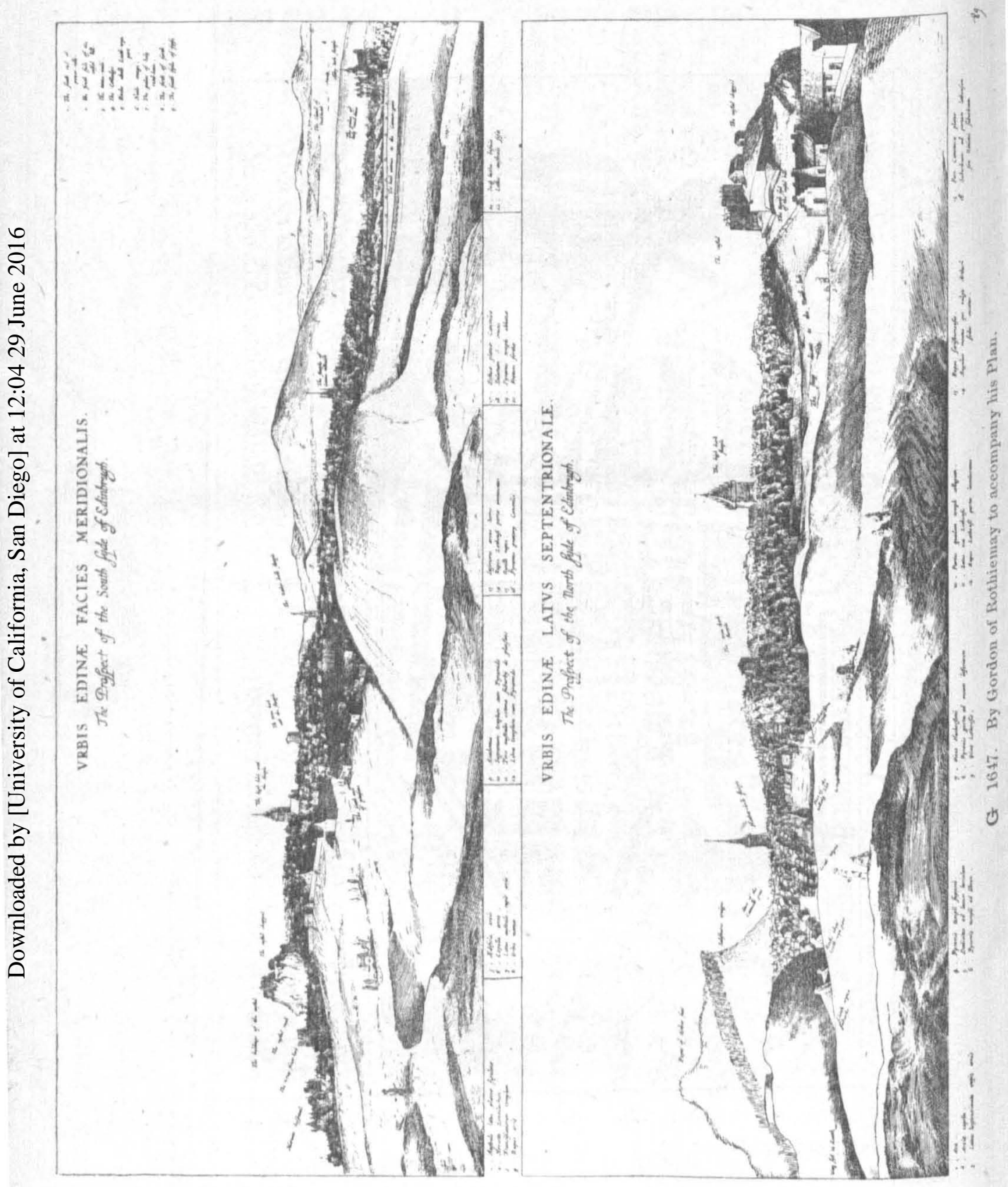




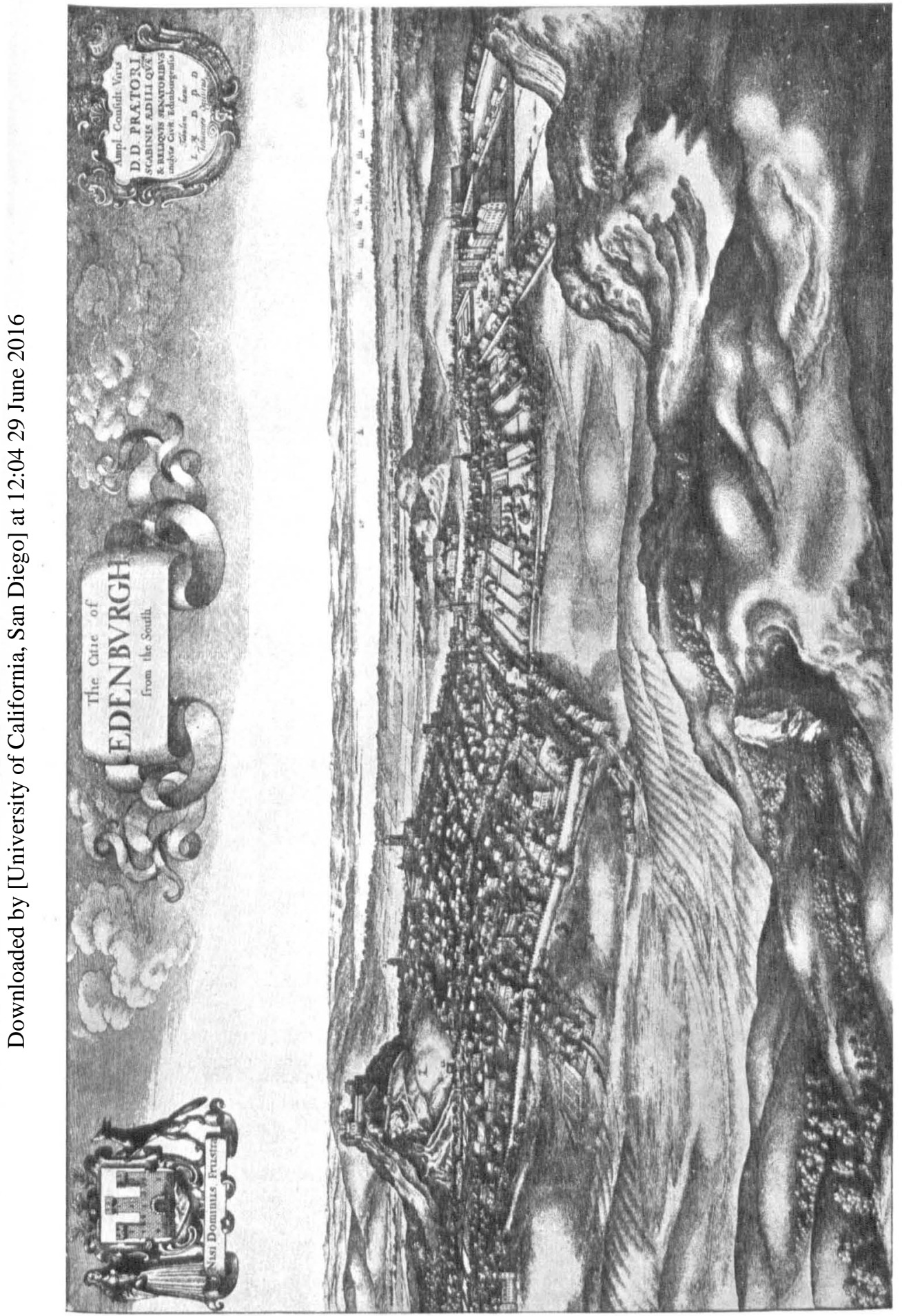



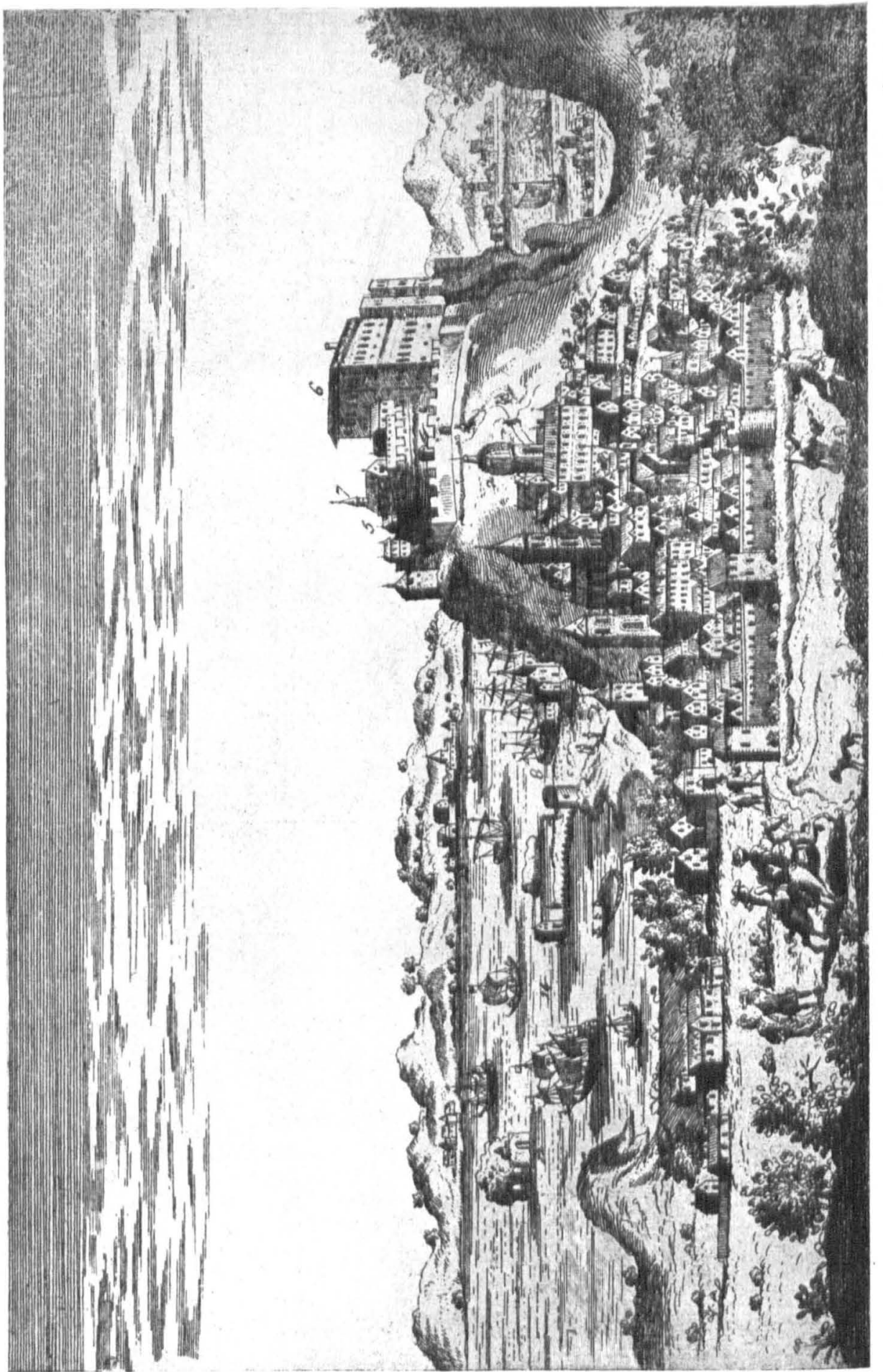
after 1836 Lizars' maps are undated, and that for some years the same map appears, almost without change, in later issues. Without doubt the explanation is, that Lizars printed a very large edition-far more than could be used in one year-and when these were used up, a fresh batch was printed. In no other way can we account for the fact that different maps appear in different copies of the same year's Directory, and for the long periods elapsing between the correction of the plate. The outstanding feature by which each batch can be recognised is:-1841, Haymarket Terminus added; 1843, Newhaven Railway; 1845, North British Railway; 1847, Scotland Street Tunnel ; 1850, Granton Railway ; 1852, Caledonian Station added; 1857, Cockburn Street marked.

These Directory Maps practically held the field for twenty years, until Lancefield, with the encouragement of W. \& A. K. Johnston, completed his survey of Edinburgh in 1851 , notwithstanding the fact that the Ordnance Survey was on the point of being issued. This map was a most exquisite and fine piece of private engraving work.

As the Ordnance Survey of 1852 became the official map from that time forward, it is reproduced as being what may be called the first official map of the city.

As it is possible that there are other maps of Edinburgh than those in this list, a communication should be sent to Mr. Cowan or Mr. Inglis by any one knowing of other pre-railway period maps.

An index of sizes is given below as it is not always possible to identify undated or torn maps. The index of names on p. 327, gives those which appear on the maps, whether of surveyor, publisher, or engraver. Where no name appears on a map reference should be made to the index of sizes, from which almost any pre-railway map can be identified. Maps after 1847 can be recognised by the North British and Caledonian Railways being marked on them. Owing to the stretch or shrinkage of different papers, the neasurements are only approximate.

\section{APPROXIMATE SIZES OF THE MAPS OF EDINBURGH.}

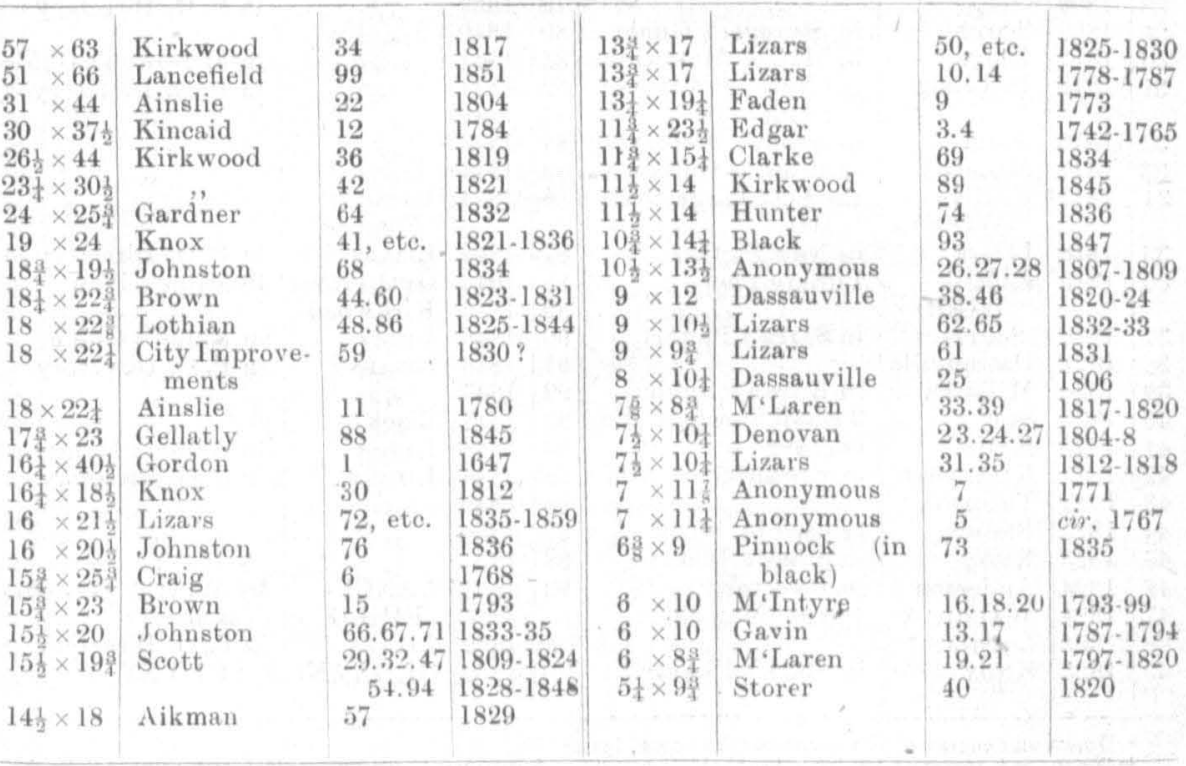




\section{CHRONOLOGICAL LIST OF MAPS OF EDINBURGH}

\section{Prior to the Ordnance Survey.}

Small type, below $12 \times 15$; Small Capitals, $12 \times 15-20 \times 25$; CAPITALS, above $20 \times 30$.

\begin{tabular}{|c|c|c|c|c|c|c|c|}
\hline 1 & 1647 & GORDON & Picture Plan & 50 & 1825 & LIzARS † & in P. O. Directory \\
\hline 2 & c 1730 & $\ldots$ & Hospital Lands & 51 & 1826 & , , & , \\
\hline 3 & 1742 & EDGAR & First City Plan & 52 & 1827 & , & \\
\hline 4 & 1765 &,, & Revision & 53 & 1828 & & \\
\hline 5 & $c 1767$ & Anonymous & & 54 & 1828 & HUNTER \& & Sмгтн (Мар 29) \\
\hline 6 & 1768 & Crate & Plan of New Town & $5 \overline{5}$ & 1829 & LOTHIAN & \\
\hline $\begin{array}{l}7 \\
8\end{array}$ & 1771 & Anonymous & & 56 & 1829 & THOMSON & in $\mathrm{P}, \mathrm{O}$. Directory \\
\hline $\begin{array}{l}8 \\
9\end{array}$ & 1773 & ARMSTRONG & on Map of Lothians & 57 & 1829 & AIKMAN & in Mackie's Ho \\
\hline 9 & 1773 & FADEN & JEI & 58 & 1830 & Тномson & in P. O. Directory \\
\hline 10 & 1778 & D. Lizars & in Arnot's History & 59 & c 1830 & LIZARS & City Iniprovements \\
\hline $\begin{array}{l}11 \\
12\end{array}$ & 1780 & A INSLIE & & 60 & 1831 & BRoWN \& & Nkíson \\
\hline $\begin{array}{l}12 \\
13\end{array}$ & 1784 & KINCAID & & 61 & 1831 & Lizars & in P. O. Directory \\
\hline 13 & 1787 & Gavin & in Kincaid's History & 62 & 1832 & & \\
\hline 14 & 1787 & D. LIzars & History & 63 & 1832 & Knox & in Roll of \\
\hline 15 & 1793 & BRowN \& & $\mathrm{W}_{\mathrm{A}}$ & 64 & 1832 & GARDNER & arlian \\
\hline 16 & 1793 & M'Intyre & tcheson's Direc. & & & & $\mathrm{Bu}$ \\
\hline 17 & $\begin{array}{l}1794 \\
1794\end{array}$ & Gavin & $\begin{array}{l}\text { tory } \\
\text { in Traveller's Com. }\end{array}$ & $\begin{array}{l}65 \\
66\end{array}$ & $\begin{array}{l}1833 \\
1833\end{array}$ & $\begin{array}{l}\text { Lizars } \\
\text { JoHnston }\end{array}$ & $\begin{array}{l}\text { in P. } 0, \text { Directc } \\
\text { in Gray's Direc }\end{array}$ \\
\hline 8 & & & 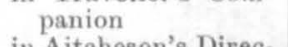 & 67 & 1834 & , , & A Gray \& Direc \\
\hline & 1796 & M'Intyre & $\begin{array}{l}\text { in Aitcheson's Direc- } \\
\text { tory }\end{array}$ & $\begin{array}{l}68 \\
69\end{array}$ & $\begin{array}{l}1834 \\
1834\end{array}$ & CrÄ̈ки & $\begin{array}{l}\text { in Pollock's } \\
\text { Turrell-Cha }\end{array}$ \\
\hline $\begin{array}{l}19 \\
20\end{array}$ & 1797 & M'Laren & wn's Guide & & & & all \\
\hline 20 & 1799 & M'Intyre & $\begin{array}{l}\text { in Aitcheson's Diree- } \\
\text { tory }\end{array}$ & $\begin{array}{l}70 \\
71\end{array}$ & $\begin{array}{l}1834 \\
1835\end{array}$ & $\begin{array}{l}\text { LIZARS } \\
\text { JOHNSTON }\end{array}$ & $\begin{array}{l}\text { in P. O. Directory } \\
\text { in Gray's Directory }\end{array}$ \\
\hline 21 & 1800 & M'Laren & in Brown's Guide & 72 & 1835 & Lrzaks & in P. O. Directory \\
\hline $\begin{array}{l}22 \\
23\end{array}$ & $\begin{array}{l}1804 \\
1804\end{array}$ & $\begin{array}{l}\text { ATNSLIE } \\
\text { Denovan }\end{array}$ & in Direc & 73 & 1835 & Pinnock & printed in black, \\
\hline $\begin{array}{l}23 \\
24\end{array}$ & $\begin{array}{l}1804 \\
1806\end{array}$ & Denovan & in New Picture of & 74 & 1836 & Hunter & lette \\
\hline & 1000 & & Fin & 75 & 1836 & & in Stark's Picture \\
\hline $\begin{array}{l}25 \\
26\end{array}$ & 1806 & Dassauville & in & 76 & 1836 & JoHNSTON & \\
\hline $\begin{array}{l}26 \\
27\end{array}$ & 1807 & Anonymous & in P.O. Directory & 77 & 1837 & Lizars & in Directory \\
\hline $\begin{array}{l}27 \\
28\end{array}$ & 1808 & ", & , & 78 & 1838 & ," & \\
\hline 28 & 1809 & & 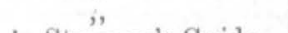 & 79 & 1839 & , & in P. O. Directory \\
\hline $\begin{array}{l}29 \\
30\end{array}$ & 1809 & ScotT & ger's Guide & 80 & 1840 & , & 3 \\
\hline $\begin{array}{l}30 \\
31\end{array}$ & 1812 & Krox & in Map of Midlothian & 81 & 1841 & , & uide \\
\hline 31 & 1812 & D. Lizars & $\begin{array}{l}\text { in New Pieture of } \\
\text { Edinburgh }\end{array}$ & $\begin{array}{l}82 \\
83\end{array}$ & $\begin{array}{l}1841 \\
1842\end{array}$ & , & . O. Di \\
\hline 32 & 1816 & Sоoтt & in Arnot & 84 & 1843 & , & \\
\hline 33 & 1817 & aren & in 1 & 85 & 1844 & & \\
\hline 34 & 1817 & $\begin{array}{l}\text { KIRK- } \\
\text { WOOD }\end{array}$ & $\begin{array}{l}\text { the Best Large-Scale } \\
\text { Map }\end{array}$ & 86 & 1844 & $\begin{array}{l}\text { LAING \& } \\
\text { ForBES }\end{array}$ & \\
\hline 35 & 1818 & Lizars & Picture & 87 & 1845 & LIZARS & in $\mathrm{P}, \mathrm{O} . \mathrm{Dir}$ \\
\hline 36 & 1819 & $\begin{array}{l}\text { KIRK- } \\
\text { WOOD }\end{array}$ & Picture 1 & $\begin{array}{l}88 \\
89\end{array}$ & $\begin{array}{l}1845 \\
1845\end{array}$ & $\begin{array}{l}\text { GeLLATLY } \\
\text { Kirkwood }\end{array}$ & in Milne's Pla \\
\hline 37 & 1820 & (Scotт) & in Stark's Picture & 90 & 1846 & Lizars & in Rhind' \\
\hline 8 & 1820 & Dassauville & & 91 & 1846 & Lizars & in $\mathrm{P} .0$. Directory \\
\hline 99 & 1820 & $M^{\prime}$ & & 92 & 1847 & & 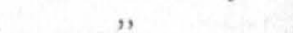 \\
\hline 40 & 1820 & Storer & N. \& 8 & 93 & 1847 & Blac & \\
\hline 41 & 1821 & & er & 94 & 1848 & $\mathrm{P}$ & rials \\
\hline 42 & 1821 & KrRKWOOD & centre sheet of 1817 & 95 & 1848 & LIZARS & in P. O. Directory \\
\hline 43 & 1822 & Thomson & & 96 & 1849 & , , & ", \\
\hline 44 & 1823 & Brown & rev & 97 & 1850 & , & \\
\hline 45 & 1823 & K nox & in Stark's Picture & 98 & 1851 & & \\
\hline $\begin{array}{l}46 \\
47\end{array}$ & 1824 & Anderson & in Directory & 99 & 1851 & LANCE- & V. \& A. K. John- \\
\hline $\begin{array}{l}47 \\
48\end{array}$ & 1824 & WATIGH \& & INNES (Map 29) & & & FIELI & \\
\hline 48 & 1825 & Lothian * & & 100 & 1852 & LTZARS & in P. O. Directory \\
\hline 49 & 1825 & KNox & in Stark's & & 1852 & DNA & E SURVEY \\
\hline
\end{tabular}

* Drawn and engraved by George Bartholomew, 1825.

+ Drawn and engraved by John Bartholomew, 1825. Subsequent editions revised and corrected by John Bartholomew, father and son. 
ALPHABETICAL INDEX OF NAMES.

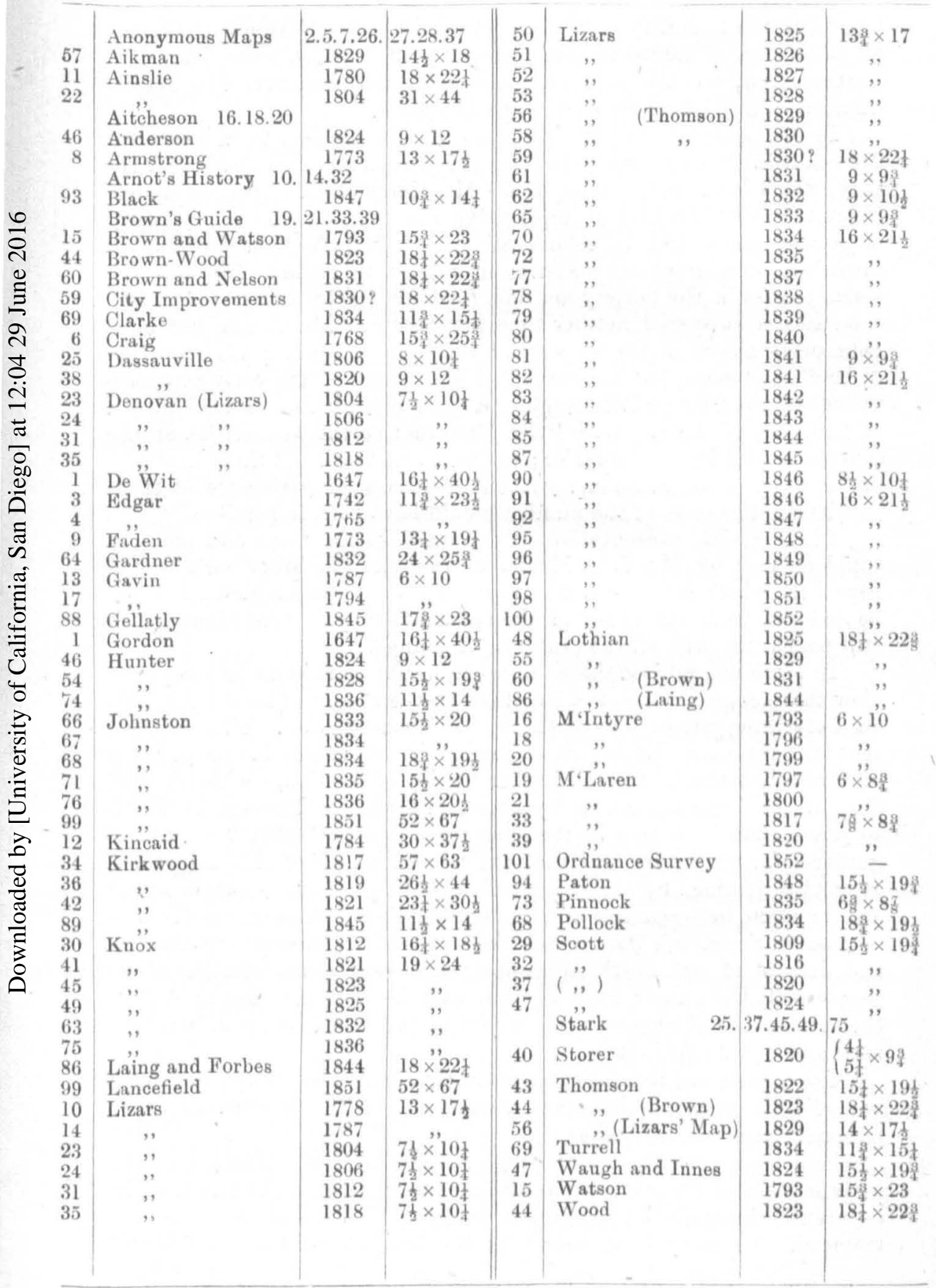

